\title{
Motivation Factors in Energy Saving Behaviour between Occupants in Green and Conventional Buildings - Malaysia Case Study
}

\author{
Nurul Sakina Mokhtar Azizi and Suzanne Wilkinson
}

\begin{abstract}
Previous studies showed that green buildings may influence occupants attitude and behavior. However, there was limited understanding on how green building influences occupants attitude and behavior. The objective of this paper investigates are green building occupants motivation to save energy different to conventional building occupants. The innovativeness of this study is that it compares the motivation factors between green and conventional buildings, as previous studies have not compared between both building types. The findings in this paper showed that both certified and non-certified green buildings motivated half of the occupants to practice energy saving behaviour.
\end{abstract}

Index Terms-Energy saving behaviour, motivation, green buildings, office buildings.

\section{INTRODUCTION}

Studies found that occupants in green buildings practices energy saving behaviour better than in conventional buildings [1]-[3]. There is a common consensus among scholars that showed working in green buildings motivates occupants' energy saving behaviour. For example, Steinberg et al., [3] found that the occupants' energy saving behaviour were encouraged by the green building certification and wanted to ensure building performance success. Azizi et al., [1] found that occupants' energy saving behaviour practice is encouraged by the pro-active building managers in the green buildings to assist with energy saving behaviour. Azizi et al., [4] also found the occupants energy saving behaviour is encouraged because they believed that working in a green building means that they are willing to reduce their comfort demand and adapt to save energy. Kato et al., [5] found that the staff in the green buildings agreed that they felt loyal to their organisation because of its sustainability practices and policies. Deuble and Dear [6] showed that occupants in the green buildings are more environmentally concerned than occupants in the conventional buildings.

While the studies mentioned above have demonstrated that working in green buildings motivates energy saving behaviour practice, there are also studies that showed green buildings do not motivate occupants' energy saving behaviour. For example, Kato et al., [5] findings contradicted to Steinberg et al., [3] which found that green building certification does not necessarily encourage staff to be environmentally conscious. Kato et al., [5] discovered that there is a gap between managers and staff on how green certification affects environmentally friendly behaviours within office. The managers of the green buildings believed that working in a certified green building helped motivate their staff to be more environmentally friendly. While the staff did not believe green certified office status encouraged them to be environmentally conscious. Lynam [7] findings contradicted to Deuble and Dear [6] which showed that occupants in conventional buildings are more environmentally concerned than occupants in green buildings.

Therefore, it can be concluded that studies on whether working in green buildings motivates occupants' energy saving behaviour or not is inconsistent and remain unclear. The objective of this paper examines whether occupant's perception working in a green building encourages them to practice energy saving behaviour. The paper also examines occupants' perception on themselves in practicing energy saving behaviours.

In understanding occupants' motivation to practice energy saving behaviour, the focus in the previous studies has been much on the occupants' perception towards green building, and the management of the building. There are limited studies that examine the influence of green building on occupants' key motivation to practice energy saving behaviour. There are three key motivation factors which are believed to encourage energy saving behaviour practice. The motivations are 1) knowing that energy scarcity is a global issue 2) knowing that the energy costs can be saved 3) wanting to set an example to others.

Hence, the overall aim in this paper is to gain better understanding on the influences of green buildings on occupants' motivation to practice energy saving behaviour. The objective of this paper is to examine whether occupant's motivation to practice energy saving behaviour in green buildings are different to occupants in conventional buildings. Another objective of this paper is to determine which of the motivation factors are most important for the occupants to practice energy saving behaviour. The paper also addresses strategies preferred by occupants to increase energy saving behaviour practice.

\section{Motivation FACTORS That ENCOURAGE ENERGY SAVING BEHAVIOUR}

There are limited studies that examine the influence of green building on occupants' key motivation to practice
Manuscript received June 15, 2014; revised August 10, 2014. This work was supported in part by the University
and University Science of Malaysia.

The authors are with the Civil Engineering Department, University of Auckland, New Zealand (e-mail: sakinamokhtar@gmail.com, s.wilkinson@ auckland.ac.nz). 
energy saving behaviour

\section{A. Knowing that Energy Scarcity Is a Global Issue}

Limited studies examine the relationship between level of concern for the environment and level of practice in pro-environmental behaviour in office buildings [8], [9]. Nevertheless, Ucci et al., [10] suggests that energy saving behaviour in office buildings are more likely encouraged by the concern for the environment issues rather than knowing the amount of energy cost reduced since the energy cost are not paid by the occupants. In addition, Tovey and Turner [11] demonstrated significant energy reductions by raising energy awareness among occupants in the office buildings. Tovey and Turner [11] targeted a particular day in which all students and staff were encouraged to think about the energy they were using and switch off whenever possible. Results on the energy profile showed a substantial reduction in energy usage for lighting load on the targeted day. Therefore, the suggestion shows that concern for the environment is a key motivator to practice energy saving behaviour. This paper examines whether knowing that energy scarcity is a global issue is an important motivator for occupants in office buildings to practice energy saving behaviour.

Occupants' attitudinal factors in office buildings are influenced by the value of the organisation [12]-[15]. The values of the organisation are such as the characteristic of the building that are green designed and certified as green. The value of green buildings is increased as it represents an initiative to reduce the environmental impact globally by consuming less energy as compared to conventional buildings [16]. Furthermore, Lynam [7] also suggests that green buildings have the potential to send out pro-environmental message to occupants.

Nevertheless, studies showed uncertainty findings to whether green buildings increases occupants' level of awareness on the environmental issues. For example, Deuble and Dear [6] found that green building increased occupants' level of awareness on environmental issues. While Lynam [7] and Kato et al., [5] findings contradicted to Deuble and Dear [6] which found that green building does not increase occupants' level of awareness on environmental issue. These studies imply that there are uncertainties to whether green buildings motivates occupants to practice energy saving behaviour due to the potential that occupants have increased concern on the environmental issue. Furthermore, these studies did not examine whether knowing the environmental issue motivated the occupants to practice energy saving behaviour. This paper examines the influence of green buildings on occupants' level of concern on the environmental issue of energy scarcity.

\section{B. Knowing that I Can Help to Save Energy Cost}

Reducing energy cost is not a key motivator to practice energy saving behaviour for staff in commercial buildings, since the individuals do not pay the energy bills [8]. However, reducing energy cost can be a key motivator for occupants in commercial buildings if the occupants know where the financial gain goes to. According to value-belief-norm theory of environmentalism, a concern with the welfare of others is also predictive of pro-environmental behaviour [14].

For example, the energy efficient guideline for commercial buildings developed by Energy Efficiency Conservation Authority (EECA), New Zealand [17] suggests saving money for the company, and donating the money saved to charity can motivate occupants to practice energy saving behaviour. Christina et al., [18] found that staffs in office buildings are motivated to practice energy saving behaviour if the profit gained by the energy costs savings were shared by the staff.

Green buildings are design intended to be energy efficient than conventional buildings [19]-[22]. Since the operating cost per square meter in a green building is lower than a conventional building [23]-[26], occupants may increase their energy consumption. Many studies in the residential buildings showed that when there is an improvement in technical efficiency in the use of energy, the occupants are more likely to increase their energy consumption[27]-[29] Occupants may choose to use a heater for longer periods or to a higher temperature because the operating cost per square metre has reduced [30]. Scholars have termed this behaviour as the rebound effect [31]-[34]. The findings revealed that in situations where there is rebound effect behaviour, the occupants are motivated to reduce their energy consumption when there is an increase in the energy cost. Hence, this shows that knowing the amount of energy cost can be a key motivator to practice energy saving behaviour especially in buildings that have rebound effect behaviour.

\section{I Want to Set an Example to Others}

Studies have found that occupants in green buildings are more inspired to reduce energy usage than occupants in conventional buildings [1], [3], [5]. The studies indicate that occupants in green buildings perhaps have higher eagerness to be exemplars to others as they feel that they are representing the place they work in. This corresponds to the social identity theory that individual's behaviour is highly influenced by the social environment [35]. Furthermore, the social environment and the social norms play a significant role in promoting pro-environmental behaviours [36]. Hence, this paper intends to investigate whether occupants in green buildings are motivated to become exemplars of practicing energy saving behaviour to others.

In addition, identifying energy champions in an organisation is mentioned as one of the key energy management strategies in reducing energy usage [37]. Therefore, this paper examines occupants whether they aspire to become exemplars to other building users will indicate the number of energy champions that exist.

\section{RESEARCH METHODOLOGY}

\section{A. Case Study Description}

Three case study buildings were selected to examine whether occupants motivation to practice energy saving behaviour in green buildings are different to occupants in the conventional building; a Green Building Index -certified green building; a non-certified building with "green" features; and a conventional building. The Low Energy Building (LEO) is identified as Green Building Index-certified green building. Perbadanan Putrajaya (PPJ) is identified as a non-certified green building with the design intent to be energy efficient. The Ministry of Health $(\mathrm{MoH})$ is identified as a conventional building with no specific energy 
saving elements.

1) Case study 1- low energy office (LEO) - green certified

The LEO building was built as the first government energy efficient building in 2004 housing the Malaysian Ministry of Energy, Green Technology and Water. The LEO building is situated in Putrajaya, Kuala Lumpur, a city that is aiming to be a sustainable city with a master plan of theme "City in a Garden and the Intelligent City". The LEO building won the ASEAN Best Practice Energy Efficient building in 2006 and received the Platinum certificate awarded by Green Building Index in 2011. The main energy efficient features include adopting a variable air volume (VAV) system which is energy efficient compared to a typical air-conditioning system. The atrium is naturally ventilated and has large access to natural daylight through skylights. Occupancy and photo sensors are installed in the building. Solar photo-voltaic are installed at the roof top of the building to provide renewable energy for a water wall feature in the atrium. The building has a double roof to provide additional shading. The windows incorporate low emission glazing. A spray mist system which emits water particles is installed at the sliding doors to cool natural ventilation.

There are energy management strategies applied to occupants in the LEO building. For instance, management put up posters on energy efficiency features of the building. An energy awareness campaign through pamphlets and emails to staff are also conducted from time to time. Attending training and seminars on energy efficiency are incorporated as one of the key performance indicators for staff. Briefing on the objectives and goals of the organization's commitment to energy efficiency are given to new employed staff. In addition, LEO has reminder stickers to switch off lights, computer monitors and also sticker reminder to close doors in spaces that are air-conditioned. The building manager in the LEO building periodically updates the occupants on energy consumption of the building. In addition, management encourages staff to work together to identify opportunities for further improvement. A display monitor that reports current energy consumption of the building is placed at the lobby area. The LEO approach for managing occupant's energy usage could be considered active.

\section{2) Case study 2- Perbadanan Putrajaya (PPJ) - green (non certified)}

PPJ building situated in Putrajaya built in 2008 is known for its contemporary traditional Islamic architecture. It was also designed to incorporate energy efficiency features. PPJ won the ASEAN Energy Award in 2008. However, PPJ management did not apply for green certification. The main energy efficient features in PPJ are the adoption of a variable air volume (VAV) system. The building is highly glazed with double tempered green glass with no emission glaze. The building consists of floating meeting rooms which are naturally ventilated. Occupancy and photo sensors are installed in the building. A plant irrigation system controlled by an individual rain sensor is installed.

The energy management strategy applied in PPJ includes reminder stickers to switch lights off, and close doors in spaces that are air-conditioned. No reminder stickers are provided encouraging occupants to shut computers off. The
PPJ building manager reminds staff to switch off lights during office lunch hour by assigning a representative on each floor. Manual switching off of lights has to be done in some areas since some of the lights are not connected to the energy management system. The PPJ building does not have energy efficient information circulated to the staff. The staffs in the PPJ building are not informed on the energy consumption of the building. The PPJ approach for managing occupant's energy usage could be considered semi-active.

\section{3) Case study 3- ministry of health (MoH), Putrajaya-} conventional building

The MoH building was built in 2008 adjacent to the PPJ building. The building was designed to be a contemporary building which emphasizes transparency and dynamism in forms. Even though the building installed double glazing with a low thermal emissivity layer it has no extra features and is considered a conventional building. Discussion with the $\mathrm{MoH}$ architect and report analysis of the façade building assessment suggests that the building requires constant artificial lighting instead of optimization of daylight usage. The building has low visible light transmittance and high indoor reflectance which causes the façade to look dark and has a 'mirror' effect when viewed from the exterior.

The energy management strategy applied in $\mathrm{MoH}$ includes reminder stickers to switch lights off, but not reminders for computers. The $\mathrm{MoH}$ building does not circulate energy efficiency information to the staff, nor does it provide updates on energy consumption to staff. The MoH approach for managing occupant's energy usage could be considered passive.

\section{B. Research Method}

Invitations to participate in this study were sent through an e-mail and a follow up call to the building managers was made. The building managers in each of three case study buildings then distributed an online survey uploaded onto the building website to the occupants in the buildings. The researcher conducted a follow up e-mail requesting the building manager to circulate the website link to the occupants in the building after two weeks. Hardcopies were also provided to the building manager for respondents who wished to fill in the questionnaire manually. In order to increase the response rate, the researcher was given access to the case study buildings to invite participants in the research face to face. Hardcopies as well as the website link were given to interested participants.

A survey was conducted in the three case study buildings to evaluate occupants' motivation to practice energy saving behavior. The three key motivation factors identified are:

- "knowing that energy scarcity is a global issue"

- "knowing that I can help to save energy costs"

- "I want to set an example to others"

This paper does not intend to focus on measuring environmental beliefs of the occupants alone. Hence, the New Ecological Paradigm survey, which consists of 15 items was not used as it is considered as lengthy. A short question asking respondents to rate the importance of knowing that energy scarcity is a global issue using a Likert scale of 5 was asked [38]. Similar scales were adopted for the rest of the factor.

Analysis using SPSS Statistic 22 software was used to run 
the statistical relevance of the research. The Man U Whitney test was used to identify which of the motivational factor is significantly different between the two building types. Motivation factors identified as significantly different via Man U Whitney test were further analysed using frequency description and crosstab analysis to ascertain occupants in which of the building type have the most important motivation factor.

In order to gain better understanding on occupants motivation to practice energy saving behaviour, the respondents were asked their perception of certified and non-certified green buildings in influencing them to practice energy saving behaviour. Respondents were asked to rate the importance level of factors that motivate them to practice more energy saving behaviour. The factors were "Working in a green building that is certified by the Green Building Council (GBC)", and "Knowing that this building has green features without formal recognition from Green Building Council (GBC)". A Lickert scale of 5-Very Important to
1-Not Important was used. Frequency analysis was used to identify the highest percentage of response for each factor.

To examine occupants' perception whether there is rebound effect in green buildings. The occupants in the green buildings were asked to rate their agreement on the statement "I don't need to reduce my energy consumption since this building is already designed to be energy efficient". A lickert scale of 5-Strongly Agree to 1-Strongly Disagree was used. Frequency analysis was used to identify the majority of the occupants response.

\section{RESUlTS AND DisCUSSION}

The building managers estimated that there were 1640 people in the three buildings. A total of 311 questionnaire surveys were sent out. 267 respondents were received giving a response rate of $86 \%$. Table I shows the breakdown response rate in each building.

TABLE I: RESPONSE RATE

\begin{tabular}{|l|l|l|l|l|l|l|l|}
\hline $\begin{array}{l}\text { Type of } \\
\text { Building }\end{array}$ & $\begin{array}{l}\text { Sample } \\
\text { Size }\end{array}$ & $\begin{array}{l}\text { Total Respondents } \\
\text { Received }\end{array}$ & $\begin{array}{l}\text { Response } \\
\text { rate }\end{array}$ & $\begin{array}{l}\text { Name of } \\
\text { Building }\end{array}$ & $\begin{array}{l}\text { Sample } \\
\text { Size }\end{array}$ & $\begin{array}{l}\text { Respondents } \\
\text { received }\end{array}$ & $\begin{array}{l}\text { Response } \\
\text { rate }\end{array}$ \\
\hline Conventional & 217 & 61 & $28 \%$ & MoH & 217 & 61 & $28 \%$ \\
\hline Green & 288 & 206 & $72 \%$ & PPJ & 260 & 110 & $42 \%$ \\
\hline & & & & LEO & 181 & 96 & $53 \%$ \\
\hline Total & 311 & 267 & $86 \%$ & TOTAL & 311 & 267 & $86 \%$ \\
\hline
\end{tabular}

\section{A. Knowing that Energy Scarcity Is a Global Issue}

Results from the Man-U Whitney test showed that green buildings do not influence occupants' level of awareness on the environmental issues. The results in Man-U Whitney test showed no statistical significant difference in the responses in Fig. 1 between green and conventional buildings ( $p=$ 0.292). The findings in this paper adds evidence to the literature by showing consistent findings to Kato et al., [5] and Lynam [7] where green buildings does not increase occupants level of awareness on environmental issues. Nevertheless, the finding in this paper contradicts to Deuble and Dear [6] which found that green buildings increased occupants' level of awareness on the environmental issues. Therefore, the findings in this paper showed that the status of green buildings representing as an initiative to mitigate the environmental impact does not increase occupants' level of awareness on the environmental issues.

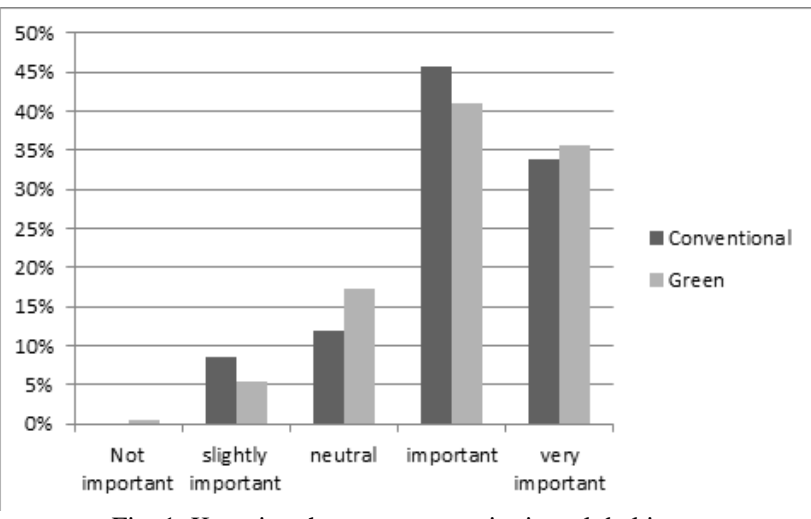

Fig. 1. Knowing that energy scarcity is a global issue.

The results in Fig. 1 show that occupants felt encouraged practicing energy saving behaviour by knowing that energy scarcity is a global issue. Examining Fig. 1, the results show that approximately $80 \%$ of the occupants in green and conventional buildings believed that environmental issue is an important motivator for them to practice energy saving behaviour. The findings supports Ucci et al., [10] whom predicted that occupants in commercial buildings are more likely encouraged by the concern for the environment issues. The findings also support Stern [14] who proposed the value of belief norm theory of environmentalism where a concern for the environment is predictive of pro-environmental behaviour.

\section{B. Knowing that I Can Help to Save Energy Costs}

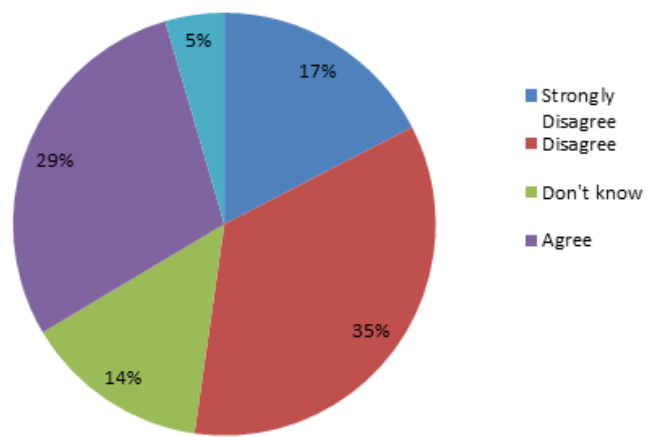

Fig. 2. I don't need to reduce my energy consumption since this building is already designed to be energy efficient.

The results from the Man-U Whitney test showed that green buildings do not influence occupants' motivation to reduce energy costs. The results in Man-U Whitney test showed no statistical significant difference in the responses between green and conventional buildings ( $p=0.357)$. Occupants are more likely motivated to reduce energy consumption for the purpose of saving energy costs in cases when there is rebound effect in the buildings [27]-[29]. The 
green buildings in this paper showed no rebound effect as shown in Fig. 2, perception of majority of the occupants at $52 \%$ disagreed/strongly disagreed that they do not need to reduce their energy consumption since green buildings are energy efficient. This explains why the motivation to practice energy saving behaviour for the purpose of saving energy costs showed no difference between occupants in green and conventional buildings. The finding is aligned with Qui [39] which also found no rebound effect in office buildings.

Examining Fig. 3, the results showed approximately $80 \%$ of the occupants in green and conventional building believed that knowing that their actions would help to save costs is an important motivator for them to practice energy saving behaviour. These findings supports the energy efficient guideline for commercial buildings developed by Ministry of Energy, Green Technology and Water (MGGTW), Malaysia [40] and Energy Efficiency Conservation Authority (EECA), New Zealand [37] which suggests saving money for the company. However, it is recommended that the MGGTW, Malaysia to donate the money saved to charity such as recommended in EECA which is believed to motivate more occupants to practice energy saving behaviour. Showing concern for the welfare of others have shown to be more effective in encouraging energy saving behaviours. The finding is also consistent with Christina et al., [41] where occupants in the commercial building were motivated to practice energy saving behaviour by knowing the amount of energy costs gained. The occupants were motivated to help the organisation save money for the company provided that they shared the profit gained in saving energy costs.

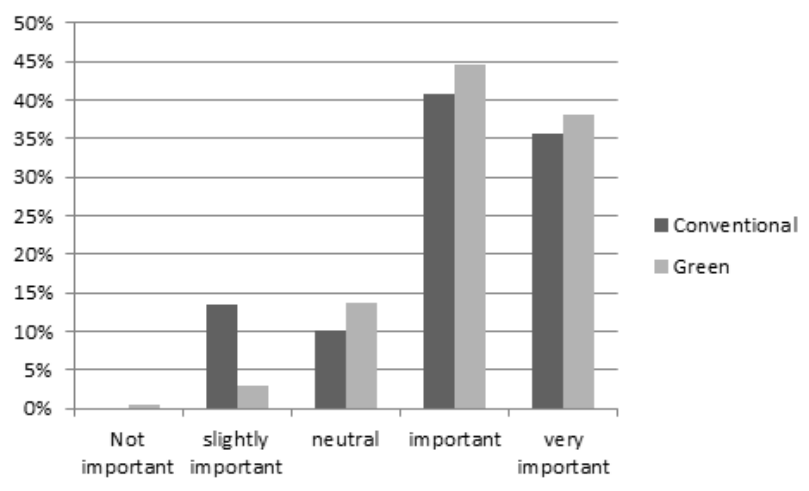

Fig. 2. Knowing that I can help to save energy costs.

\section{I Want to Set an Example to Others}

Green buildings do not influence their occupants to be motivated to become exemplars of practicing energy saving behaviour to others. This is seen from the statistical analysis Man-U Whitney test where results showed no significant difference in the responses between green and conventional buildings $(p=0.185)$. Examining Fig. 4 , the findings reveal that occupants in green and conventional buildings are both motivated to be energy champions in an organisation. Results in Fig. 4 showed that $72 \%$ of occupants in green buildings and $64 \%$ occupants in conventional buildings selected either very important/important/slightly important when asked whether they felt it was important for them to be an example to others by practicing energy saving behaviour. The findings supports the suggestion proposed in the energy efficient guideline for commercial buildings developed by EECA [17] in New Zealand which was to identify energy champions in an organization. Improvement to the energy efficient guideline developed by MGGTW [40] in Malaysia can be achieved by incorporating this into their guideline as a key strategy to reduce energy consumption.

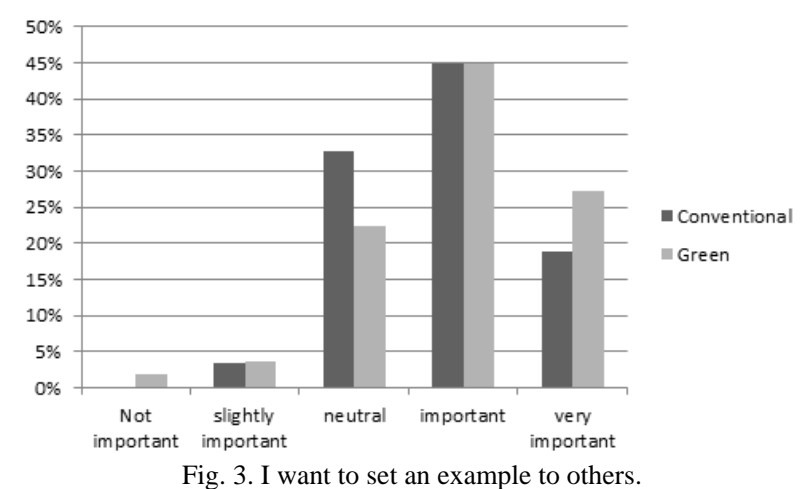

\section{Does Working in Green Buildings Encourage Energy Saving Behaviour?}

Results in Fig. 5 and 6 showed that more than $50 \%$ of the occupants believed that working in a green building encourage occupants to practice energy saving behaviour. Results in Fig. 5 show that $70 \%$ of the occupants from non-certified green building believed working in a certified green building is important (either slightly important, important, and very important). The results in this paper supports finding by Steinberg et al., [3] where occupants claimed to be more willing to practice energy saving behaviours if the green building is certified to help ensure building performance success. Hence, the result from this paper adds more evidence to the literature showing that energy saving behaviours can be practiced more frequently when green buildings are certified.

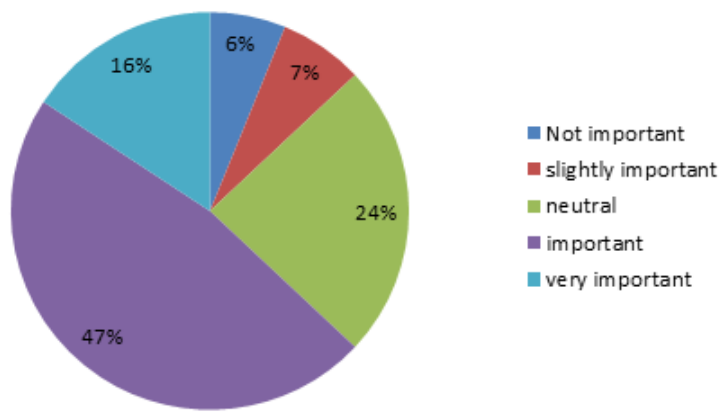

Fig. 4. Importance of working in a green building that is certified by green building council (GBC) on energy saving behaviours.

Occupants were also asked whether by just knowing that the building they work in has green features without certification by Green Building Council would be an important motivation factor for them to practice more energy saving behaviour. Results in Fig. 6 showed that $64 \%$ selected important (either slightly important, important, and very important), $7 \%$ selected 'not important', while the $29 \%$ remained neutral. The findings demonstrates even if the green buildings did not receive green certification from Green Building Index, occupants would still feel motivated to practice energy saving behaviour provided that they know the building they work in is designed green. In addition, one of the respondents commented that the concept of green 
buildings is not only focused on the design of the buildings, but occupants should also be aware on the changes of behaviour which helps to save energy. The findings in this paper does not support suggestion by Carbon Trust [42] and Azizi et al., [43] that green buildings are encouraged to be certified. This finding in this paper questions the importance of green certification in increasing energy saving behaviour practice. In addition, the findings expand the work by Deuble and Dear [6] by showing that the perception of working in a green building does not explain why Deuble and Dear [6] found more occupants in green buildings being environmentally concerned than occupants in conventional buildings. There are perhaps other factors that are not covered in this paper to understand better on the reasons for the behaviour.

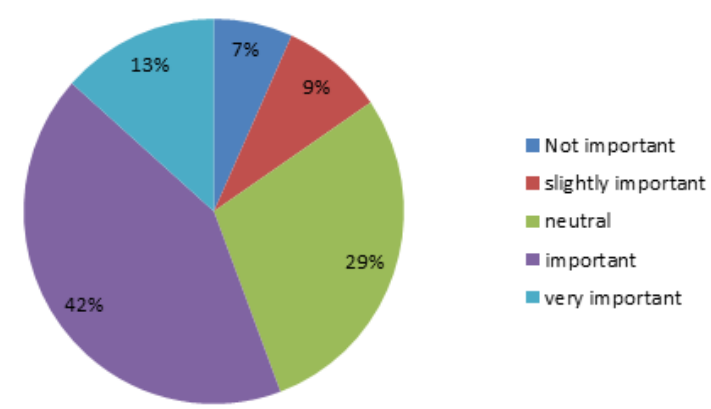

Fig. 5. Importance of knowing that this building has green features without formal recognition from Green Building Council (GBC).

\section{E. Self-Perception on Energy Saving Behaviour}

The results from Man U Whitney test showed no significant difference in how they perceive themselves on the extent level of practicing energy conservation $(p=0.652)$. However, previous study Azizi et al., [1] have demonstrated that there are more occupants in the green buildings than in the conventional building that practices energy saving behaviour. Results in Fig. 7 showed that occupants in green and conventional building both perceive themselves as good practice (approximately $45 \%$ ).

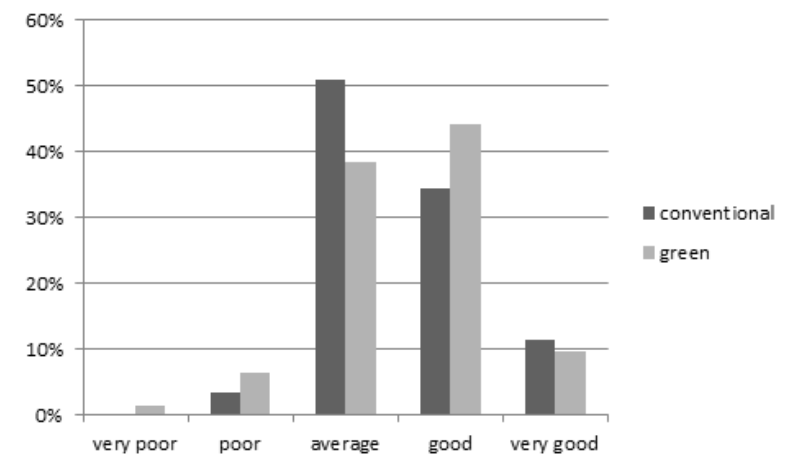

Fig. 6. How would you rate yourself in terms of practicing energy saving behaviour at work?

\section{CONCLUSION}

This paper provided a clearer understanding as to whether working in green buildings motivates occupants' energy saving behaviour. The findings in this paper showed that both certified and non-certified green buildings motivated half of the occupants to practice energy saving behaviour.

The findings in this paper also revealed that occupants in both green and conventional buildings perceived themselves as practicing good energy saving behaviours, although the prerequisite study of this paper found that occupants in the green buildings were practicing better energy saving behaviour than occupants in conventional buildings.

The findings in this paper provided the understanding that buildings despite being designed and certified as "green" does not impose a special influence on occupants' key motivation to practice energy saving behaviour. The occupants' key motivation in the following three aspects which are (1) knowing that energy scarcity is a global issue (2) knowing that the energy costs can be saved (3) wanting to set an example to others) were the same between the green buildings and the conventional building.

\section{ACKNOWLEDGMENT}

We express our gratitude to the building managers in the case study buildings for their cooperation, and assistance throughout this study. Lastly, we highly appreciate all the responses received by the building occupants in the case study buildings

\section{REFERENCES}

[1] N. S. M. Azizi, S. Wilkinson, and E. Fassman, "Strategies for improving energy saving behaviour in commercial buildings in Malaysia," Engineering Construction Architectural Management, 2014.

[2] M. G. Tajabadi, The Awareness Towards Green Office Facilities, Civil Engineeirng Department, University Technology Malaysia, University Technology Malaysia: Johor, Malaysia, 2010.

[3] D. Steinberg and M. P. C. S. A. Landis, "Determining adequate information for green building occupant training materials," Journal of Green Building, vol. 4, no. 3, pp. 143-150, 2010.

[4] N. S. M. Azizi, S. Wilkinson, and E. Fassman, "A comparitive analysis on occupants response to discomfort in green and conventional buildings - New Zealand case studies," Journal of Energy and Buildings, 2014.

[5] H. Kato, A. Murugan, and L. Armitage, Performance \& perceptions of green buildings, Institute of Sustainable Development and Architecture, Bond University: Green Building Council Australia, 2010.

[6] M. P. Deuble and R. de Dear, "Green occupants for green buildings: The missing link?" Building and Environment, vol. 56, pp. 21-27, 2012.

[7] S. Lynam, Academic Architecture: Buildings to Communicate a Pro-Environmental Message, Royal Roads University (Canada): Canada, p. 99, 2007.

[8] L. Andersson, S. Shivarajan, and G. Blau, "Enacting ecological sustainability in the MNC: A test of an adapted value-belief-norm framework," Journal of Business Ethics, vol. 59, no. 3, pp. 295-305, 2005.

[9] C. Scherbaum and P. Popovich, "Exploring Individual-Level Factors Related to Employee Energy-Conservation Behaviours at Work," Journal of Applied Social Psychology. vol. 38, no. 3, pp. 818-835, 2008.

[10] M. Ucci et al., "Behaviour change potential for energy saving in non-domestic buildings: Development and pilot-testing of a benchmarking tool," Building Services Engineering Research and Technology, vol. 35, no.1, pp. 36-52, 2014.

[11] K. Tovey and C. Turner, "Carbon reduction strategies at University of East Anglia, United Kingdom," Proceedings of the Institution of Civil Engineers, London, pp. 193-201, 2006.

[12] I. Ajzen, "The theory of planned behavior," Organizational Behavior and Human Decision Processes, vol. 50. no. 2, pp. 179-211, 1991.

[13] L. M. Andersson and T. S. Bateman, "Individual Environmental initiative: Championning natural environmental issues in the U.S business organizations," Academy of Management Journal, vol. 43, no. 4, pp. 548-570, 2000.

[14] P. C. Stern, "Toward a coherent theory of environmentally significant behavior". Journal of Social Issues, vol. 56, no. 3, pp. 407-424, 2000.

[15] M. Davis and R. Challenger, Environmentally Sustainable Work Behaviours, Wiley Encyclopedia of Management: Organizational Behavioru: Wiley, Chichester, UK, vol. 11, 2013. 
[16] WGBC. How green building is shaping the global shift to a low carbon economy. World Green Building Council 2009. [Online]. Available: http://www.nzgbc.org.nz/images/stories/downloads/public/Knowledg e/reading/World_GBC_Report_Nov09.pdf

[17] EECA. (2010). Staff awareness and motivation-saving energy with people power. [Online]. Available: http://www.eecabusiness.govt.nz/sites/all/files/EECA\%20Business\%2 0Staff $\% 20$ Awareness $\% 20$ and $\% 20 \% 20$ Motivation $\% 20$ booklet $\% 20 \mathrm{Fe}$ bruary\%202010.pdf.

[18] S. Christina et al., "How organisational behaviour and attitudes can impact building energy use in the UK retail environment: a theoretica framework," Architectural Engineering and Design Management, vol. 10, no. 1-2, pp. 164-179, 2014

[19] S. Kubba, "'Green' and 'sustainability' defined," Green Construction Project Management and Cost Oversight, Architectural Press: Boston, pp. 1-27, 2010.

[20] G. C. Wedding, "Understanding sustainability in real estate: A focus on measuring and comunicating success in green building," Dissertation, Department of Environmental Sciences and Engineering, University if North Carolina: North Carolina, United States. p. 144, 2008.

[21] Z. B. Brown, "Occupant comfort and engagement in green buildings: Examining the effects of knowledge, feedback, and workplace culture," PhD Thesis, The Faculty of Graduate Studies, University of British Columbia, p. 192, 2009.

[22] R. E. Zigenfus, Element Analysis of the Green Building Process, Department of Civil Engineering Technology, Rochester Institute of Technology, New York, p. 96, 2008.

[23] G. Kats et al., Greening Buildings and Communities: Costs and Benefits, Washington: Good Energies, 2008.

[24] W. Bradshaw et al., The Costs and Benefits of Green Affordable Housing: Opportunities for Action, New Ecology and Green CDCs Initiative, 2005.

[25] C. Turner and M. Frankel, "Energy performance of LEED for new construction buildings," Final Report, New Buildings Institute Vancouver, United states, 2008

[26] B. Ross, M. López-Alcalá, and A. A. Small, "Modeling the Private financial returns from green building investments," Journal of Green Building, vol. 2, no. 1, pp. 97-105, 2007.

[27] H. Hens, W. Parijs, and M. Deurinck, "Energy consumption for heating and rebound effects," Journal of Energy and Buildings, vol. 42, pp. $105-110,2010$.

[28] B. Lin and X. Liu, "Electricity tariff reform and rebound effect of residential electricity consumption in China," Energy, vol. 59, pp. 240-247, 2013

[29] G. M. Huebner, J. Cooper, and K. Jones, "Domestic energy consumption - What role do comfort, habit, and knowledge about the heating system play?" Energy and Buildings, vol. 66, pp. 626-636, 2013.

[30] S. Sorrell, J. Dimitropoulos, and M. Sommerville, "Empirical estimates of the direct rebound effect: A review," Energy Policy, vol. 37, no. 4, pp. 1356-1371, 2009.

[31] Energy Saving Trust. (2013). Are you a victim of rebound? [Online]. Available:

http://www.energysavingtrust.org.uk/Take-action/Reduce-your-carbo n-footprint/Are-you-a-victim-of-rebound

[32] R. Galvin, "Making the 'rebound effect' more useful for performance evaluation of thermal retrofits of existing homes: Defining the "energy savings deficit' and the 'energy performance gap'," Energy and Buildings, 2014, vol. 69, pp. 515-524.

[33] J. D. Khazzoom, "Economic implications of mandated efficiency in standards for household appliances," The Energy Journal, vol. 1, no. 4 , pp. 21-40, 1980.

[34] J. D. Khazzoom and S. Miller, "Economic implications of mandated efficiency standards for household appliances: response to Besen and
Johnson's comments," Energy Journal, vol. 3, no. 1, pp. 117-124, 1982.

[35] B. E. Ashforth and F. Mael, "Social identity theory and the organization," The Academy of Management Review, vol. 14, no. 1, pp. 20-39, 1989.

[36] M. Ucci, "Sustainable Buildings, pro-environmental behaviour and building occupants: A challenge or an oppurtunity?" Journal of Retail \& Leisure Property, vol. 9, no. 3, pp. 175-178, 2010.

[37] EECA. (2010). Staff awarness and motivation-saving energy with people and power. Energy Management Programme, Energy Efficiency Conservation Authority (EECA) Business. [Online]. Available:

http://www.eecabusiness.govt.nz/sites/all/files/EECA\%20Business\%2 OStaff\%20Awareness\%20and\%20\%20Motivation\%20booklet $\% 20 \mathrm{Fe}$ bruary\%202010.pdf

[38] R. Lickert, "A technique for the measurement of attitudes," Archives of Psychology, vol. 140, pp.1-55, 1932

[39] Y. Qiu, "Energy efficiency and rebound effects: an econometric analysis of energy demand in the commercial building sector," Environmental and Resource Economics, 2013, pp. 1-41.

[40] MGGTW. (2010). Green practices. Ministry of Energy, Green Technology and Water (MGGTW). [Online]. Available: http://www.kettha.gov.my/portal/muatturun/dokumen/Buku\%20Elekt ronik\%20-\%20Dasar\%20Teknologi\%20Hijau\%20Negara/Amalan\%2 0hijau\%20KeTTHA/index.html\#/0

[41] S. Christina et al., "How organisational behaviour and attitudes can impact building energy use in the UK retail environment: a theoretical framework," Architectural Engineering \& Design Management, 2014 vol, 10, issue 1-2, pp. 164-179.

[42] Energy Management: A comprehensive guide to controlling energy use, CarbonTrust, 2010.

[43] N. S. A. Mokhtar et al., "Management practice to achieve energy efficiency performance: Green versus conventional office building in Malaysia," Journal of Legal Affairs and Dispute Resolution in Engineering and Construction, vol. 5, no. 4, pp. 205-214, 2012.

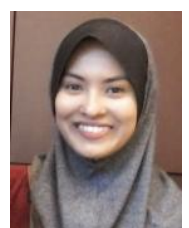

Nurul Sakina Mokhtar Azizi graduated from the University Teknologi Malaysia (UTM) in 2008 and completed a Msc degree in construction contract management from Universiti Teknologi Malaysia (UTM) in 2009. She then worked at Jabatan Kerja Raya (JKR), Kuala Lumpur and obtained a scholarship from University Scienece Malaysia (USM) to futher her PhD studies at University of Auckland, New Zealand. Her PhD research interest is in the area of energy efficiency performance in green buildings from the operational management aspect of the building. The research focuses on understanding how human behaviour influences in energy efficiency performance and recommend strategies to ensure its performance. She has published two international journal papers and two conference papers during her study. The output of her PhD research is intended to improve on the existing Green Building Index (GBI) rating tool in Malaysia

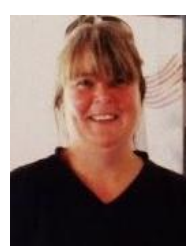

Suzanne Wilkinson is a professor of construction management in the Department of Civil and Environmental Engineering at the University of Auckland. Suzanne currently teaches and undertakes research in disaster management, construction management, construction law, and construction procurement strategies. Suzanne recently published two books: 1) Management for the New Zealand Construction Industry (co-authored with R Scofield) and 2) Construction Mediation (co-authored with P Brooker) 